\title{
O movimentado centenário do ano de ouro da ciência
}

O ano de 2005 celebra o centenário do ano de ouro da ciência. Há exatos 100 anos, Einstein formulou sua mais famosa teoria e desencadeou uma série de transformações científicas para a humanidade. Einstein dizia que "viver é como andar de bicicleta, para manter o equilíbrio, é preciso continuar se movendo". E no século $\mathrm{XX}$, principalmente a partir da segunda metade, houve um movimento acelerado. $O$ centenário ficou conhecido como aquele no qual o homem mais avançou cientificamente. Desde a invenção da penicilina até o desvendamento do genoma humano, o homem desfrutou de descobertas que lhe trouxeram melhor qualidade de vida, aumentaram sua expectativa de existência, abrandaramthe o sofrimento físico e, de quebra, solucionaram muitos dos mistérios da vida.

Quando pensamos sobre tudo isso, destacamos um aspecto importante: salvo algumas exceções - toda descoberta surgiu da pesquisa científica e todo benefício foi testado à exaustão antes de ser utilizado. O meio acadêmico, por seu envolvimento com o ensino e suas extensões, sempre proveu situações favoráveis à pesquisa, ao intercâmbio e à prática docente, sendo conseqüentemente o berço dos maiores cientistas do mundo. No Brasil, a Universidade é ainda a maior geradora de pesquisas científicas e, ultimamente, apresenta uma sintonia maior com a indústria. Esperamos que essa aproximação se traduza em agilidade para transformar a pesquisa em conhecimento aplicável e útil para a comunidade.

No que tange as comemorações desse ano para a ciência, devemos incluir a discussão sobre a relevância da pesquisa acadêmica para a sociedade em geral. Fazer pesquisa apenas para cumprir as exigências legais da faculdade, optando por um modelo já existente, é no mínimo falta de interesse pala ciência.Apesar de muitos sucumbirem diante da ineficácia dos laboratórios e equipamentos, da escassez de pessoal especializado, além da falta de verbas para a ciência nacional, há muito que se possa fazer quando o foco passa a ser a aplicação da pesquisa. Por exemplo, uma pesquisa que não acrescenta conhecimento à prática da Ortodontia, pode ser descartada ainda quando projeto acadêmico. É preciso que nossos mestres ajam com rigor e, principalmente, com abnegação para orientar seus pupilos no sentido de trazerem, senão novidades transformadoras, informações que tornem a escolha do tratamento ortodôntico mais segura para os clínicos e seus pacientes. Negar essa necessidade é desvalorizar o poder que a sociedade em geral transfere para essas instituições.

Muitos temas como o crescimento, o desempenho de novos materiais, a biologia que envolve a movimentação dentária, reações morfológicas da face diante de determinados tratamentos são assuntos que, embora pareçam batidos, ainda aperfeiçoam as soluções para o cotidiano do ortodontista. Claro que a idealização de técnicas biológicas revolucionárias e pesquisas genéticas abrangendo o contexto das más oclusões comporão, quiçá, um futuro próximo. Enquanto aperfeiçoa-se a tecnologia, novidades e descobertas devemos acreditar nas soluções que temos à mão, tornando-as plenamente claras.

$\mathrm{Na}$ concepção dessa edição levamos todos esses aspectos em consideração. Ảbordando a tecnologia e, em especial, a informática na Ortodontia, nossa entrevista traz a palavra do Dr. Cléber Bidegain Pereira, conhecido como um dos primeiros ortodontistas a falar e a utilizar o computador em seu trabalho. A inovação e a pesquisa de ponta no mundo da Odontologia passarão também, a partir dessa edição, a serem abordadas na Seção "O que há de novo da Odontologia", sob a coordenação do Dr. Jorge Faber. Num esforço para reunir o maior número possível de artigos, estamos publicando 13 estudos de variados profissionais do país. São estudos que fazem sentido não só como pesquisas acadêmicas, mas também como informações pertinentes para a especialidade. Enfim, nessas 160 páginas de ciência buscamos captar a essência do que ocorre no país da Ortodontia. Resultados de idéias e pesquisas que refletem o movimento de nossos cientistas. Queremos iniciar o ano de ouro da ciência mundial, com o ouro de nossos pesquisadores. Queremos incentivá-los a acreditarem cada vez mais no valor da ciência, no valor das pesquisas relevantes, no valor das pesquisas que são aplicadas à prática. Que continuemos nos movimentando!

Adilson Luiz Ramos Editor 